\title{
KANDUNGAN MERKURI DALAM BEBERAPA MEDIA SEKITAR PENAMBANGAN EMAS SKALA KECIL (PESK) DI KALIMANTAN TENGAH
}

\author{
MERCURY CONTENT IN SEVERAL ENVIRONMENTAL MEDIA AROUND \\ ARTISANAL SMALL SCALE GOLD MINING (ASGM) IN CENTRAL KALIMANTAN
}

\author{
Alfrida E. Suoth ${ }^{1}$, Siti Masitoh ${ }^{1}$, Alfonsus H. Harianja ${ }^{1}$, Edy Junaidi ${ }^{1}$ dan Sri Unon Purwati ${ }^{1}$ \\ Puslitbang Kualitas dan Laboratorium Lingkungan, KLHK Kawasan PUSPIPTEK Gd. 210, Tangerang Selatan \\ 15314, e-mail: idasuoth@gmail.com
}

Diterima tanggal 02 April 2020, disetujui tanggal 23 April 2020

\begin{abstract}
ABSTRAK
Penelitian mengenai kontaminasi merkuri (Hg) pada media lingkungan akibat aktivitas PESK masih diperlukan, untuk digunakan sebagai data dasar dalam perumusan rencana penghapusan dan pengurangan merkuri. Tulisan ini menyajikan hasil penelitian mengenai distribusi konsentrasi Hg akibat PESK pada perairan sungai, ikan air tawar dan sedimen di Kalimantan Tengah. Data yang digunakan adalah data hasil pengukuran P3KLL pada tahun 1999-2008 dan hasil pengukuran terbaru yang dilakukan oleh Direktorat PB3-KLHK pada tahun 2018. Analisis Hg dilakukan menggunakan Mercury Analyzer Hg-5000 metode cold vapour, preparasi contoh uji sesuai dengan Standar Internasional Jepang (JIS) dan Standar Nasional Indonesia (SNI). Hasil penelitian menunjukkan bahwa pada sebagian besar lokasi sampling menunjukkan konsentrasi merkuri dalam air sungai masih berada di bawah standar Peraturan Pemerintah Nomor 82 Tahun 2001 untuk air kelas I (0,001 mg/L), namun di 2 lokasi lebih tinggi daripada standar tersebut. Merkuri yang terkandung dalam sampel ikan air tawar dari sungai di sekitar PESK, ditemukan pada kisaran $0,08-0,224 \mathrm{mg} / \mathrm{kg}$. Nilai ini masih berada di bawah nilai persyaratan kontaminasi logam pada ikan sesuai SNI:7387 $2009(0,5 \mathrm{mg} / \mathrm{kg})$. Kandungan merkuri dalam kisaran sedimen antara 0,0291 - 0,45 mg/kg, di mana beberapa lokasi sudah berada di atas nilai baku yang di atur dalam Quality Guidelines for Freshwater of Canadian Environmental Quality (CEQ), yaitu 0,17 mg/kg.
\end{abstract}

Kata kunci: Kalimantan Tengah, media lingkungan, merkuri, pencemaran.

\begin{abstract}
Research on mercury $(\mathrm{Hg})$ contamination in environmental media around ASGM activities is still required, as a database for the formulation of mercury phasing-out and reduction plans. This paper presents the results of research on the distribution of mercury concentrations in river waters, freshwater fish, and sediments as the impact of ASGM activities in Central Kalimantan. The data used are data set from P3KLL measurements in 19992008 and the latest measurement results conducted by the PB3-KLHK Directorate in 2018. Mercury analysis was performed using Mercury Analyzer Hg-5000 cold vapor method and the preparation of test samples in accordance with Standards Japan International (JIS) and Indonesian National Quality Standard (SNI). The results indicate that in most sampling locations, the concentration of mercury in river water was still below the quality standard of class I water on the Government Regulation Number 82 Year $2001(0,001 \mathrm{mg} / \mathrm{L})$. Still, the value at two locations was higher than the quality standard. Mercury contained in freshwater fish samples from rivers around ASGM was ranging between 0,08 and $0,224 \mathrm{mg} / \mathrm{kg}$. This value is still below the value of metal contamination requirements in fish, according to SNI:7387 2009 (0,5 $\mathrm{mg} / \mathrm{kg})$. Mercury content in the sediment is ranging between 0,0291 to 0,45 $\mathrm{mg} / \mathrm{kg}$, wherein several locations are above the standard in the Quality Guidelines for Freshwater of Canadian Environmental Quality (CEQ), which is $0,17 \mathrm{mg} / \mathrm{kg}$.
\end{abstract}

Keywords: Central Kalimantan, environmental media, mercury, pollution. 


\section{PENDAHULUAN}

Merkuri (Hg) adalah logam berwarna silver dan berbentuk cair pada temperatur kamar yang banyak digunakan di berbagai sektor. Pada penambangan emas, merkuri digunakan sebagai pengikat logam (amalgam), bidang pertanian untuk produksi pestisida, untuk produksi berbagai jenis produk komersial seperti kosmetik, alat pemantauan kesehatan, amalgam gigi, lampu, dan baterai. Penambangan emas menggunakanmerkuritelahdigunakanselama beberapa dekade oleh penambang emas [1][3]. Karena kontaminasi merkuri berbahaya pada kesehatan manusia dan lingkungan, Indonesia berinisiatif meratifikasi Konvensi Minamata, dengan fokus pada penghapusan penggunaan merkuri dalam penambangan emas, terutama Penambangan Emas Skala Kecil (PESK), dimana masih banyak PESK yang masih menggunakan merkuri dalam pemrosesan bijih emas. Beberapa penelitian juga mencatat bahwa kesadaran masyarakat tentang dampak kesehatan dari penggunaan merkuri masih sangat rendah [4][5][6].

Indonesia adalah salah satu negara dengan jumlah PESK tertinggi yang tersebar di semua pulau utama, termasuk Kalimantan Tengah, salah satu provinsi di pulau Kalimantan. PESK tersebar di sekitar Kota Waringin Barat dan Palangkaraya [7]. P3KLL telah melakukan pemantauan $\mathrm{Hg}$ dalam PESK di beberapa pulau, Jawa, Sumatera, Kalimantan, dan Sulawesi sejak tahun 1999. Tujuan penelitian ini untuk membandingkan hasil konsentrasi $\mathrm{Hg}$ di Kalimantan Tengah yang dipantau oleh Pusat Penelitian dan Pengembangan Kualitas dan Laboratorium Lingkungan (P3KLL) dan Direktorat Jenderal Pengelolaan Bahan Berbahaya Beracun (Ditjen PB3). Semua lokasi pengambilan sampel di Kalimantan Tengah namun berbeda kabupaten [8][9].

Penelitian ini dilakukan untuk mengetahui distribusi konsentrasi $\mathrm{Hg}$ pada beberapa media lingkungan, yakni pada sungai, sedimen dan ikan. Sungai dianggap sebagai media yang paling mudah terkontaminasi, karena beberapa PESK langsung membuah limbah hasil pengolahan tambang ke alirannya [10]. Demikian juga sedimen, yang merupakan tempat akumulasi limbah-limbah tadi [11], [12], serta ikan yang hidup di perairan sungai tersebut [12]. Manfaat penelitian adalah untuk pembaharuan data kontaminasi merkuri akibat PESK sebagai dasar strategi untuk mengantisipasi bencana pencemaran lingkungan.

\section{METODOLOGI}

Data yang dipergunakan adalah data hasil pemantauan $\mathrm{Hg}$ pada media lingkungan di Kalimantan Tengah pada tahun 1999, 2006, 2007, dan 2008; pada posisi geografis $01^{\circ} 28^{\prime}$. $53,9^{\prime \prime}-02^{\circ} 12^{\prime} 10,1^{\prime \prime} L S$ dan $113^{\circ} 54^{\prime} 26,6^{\prime \prime}-$ $113^{\circ} 56^{\prime} 20,1^{\prime \prime}$ BT. Sampel diambil di sekitar Sungai Rungan dan Sungai Kahayan yang terletak di Kabupaten Gunung Mas, Pulang Pisau, dan Kota Palangkaraya. Pengukuran pada setiap tahun dilakukan pada sampel air sungai, sedimen, dan ikan pada sungai tersebut. Pengukuran pada tahun 2018 dilakukan dengan mengambil sampel pada air sungai, sedimen, dan ikan di 9 lokasi di sekitar Pangkut, arah utara Kota Waringin Barat.

Pengambilan sampel pada tahun 1999, 2006, 2007, dan 2008 mengikuti prosedur berikut. Titik sampling air pada sungai ditentukan di lokasi hulu, tengah dan hilir. Pengambilan contoh uji air sungai, pengawetan dan pengukuran parameter fisik dan kimia dilakukan sesuai SNI 6989.57:2008 tentang Air dan air limbah Metoda pengambilan contoh air permukaan. Lokasi pengambilan sampel sedimen sama dengan titik pengambilan air sungai. Contoh uji ikan sungai diambil dengan jaring ikan, diawetkan dengan pendinginan pada suhu $4^{\circ} \mathrm{C}$. Sampel sedimen dan ikan didestruksi menggunakan asam nitrat dan 
asam perklorat yang selanjutnya diukur menggunakan Mercury Analyzer Hg-5000 (cold vapour).

Pengambilan sampel air pada tahun 2018 meliputi sampel air sungai, sedimen dan sampel ikan. Analisis sampel air sungai mengikuti metode SNI 6989.78:2011 tentang Cara uji Raksa (Hg) secara Spektofotometri Serapan Atom (SSA) - uap dingin atau Mercury Analyzer, sampel sedimen sungai mengikuti metode SNI 06-6992.2:2004 tentang Cara uji merkuri $(\mathrm{Hg})$ secara uap dingin dengan Mercury Analyzer dan contoh uji ikan mengikuti metode SNI 2354.6: 2016 tentang Penentuan kadar logam berat merkuri (Hg) pada produk perikanan. Konsentrasi $\mathrm{Hg}$ dari seluruh sampel diukur dengan menggunakan ICP-MS [13]. Analisis data dilakukan dengan menggunakan Excel, dan hasilnya ditampilkan secara deskriptif.

\section{HASIL DAN PEMBAHASAN}

\section{Konsentrasi Merkuri pada Air Sungai}

Aliran sungai sebagai titik sampling adalah Sungai Rungan dan Sungai Kahayan di Palangkaraya yang merupakan sungai utama yang melintasi Provinsi Kalimantan Tengah (Gambar 1). Di sepanjang DAS kedua sungai tersebut terdapat kegiatan PESK yang akhir-akhir ini berkembang sampai ke Sungai Katingan di Kotawaringin Timur. Aktivitas PESK berada di Kecamatan Katingan Hilir dan Tengah dengan jenis galian emas sekunder pada lahan seluas 2.248 ha. Sistem penambangan adalah dengan menyedot dan menyemprot material tambang, dengan hasil emas diperkirakan mencapai 3-8 gram per hari. Setiap unit dikerjakan secara berkelompok, terdiri dari 3 sampai 5 orang. Merkuri digunakan pada proses pengikatan material emas yang kemudian dilepaskan lagi melalui proses pembakaran (vaporisasi).

Pada Tabel 1 ditunjukkan hasil pengukuran konsentrasi $\mathrm{Hg}$ di beberapa lokasi pengambilan contoh uji yang dilakukan mulai dari hulu sampai hilir sungai Kahayan. Pengambilan contoh uji air sungai pada 2006, 2007, dan 2008

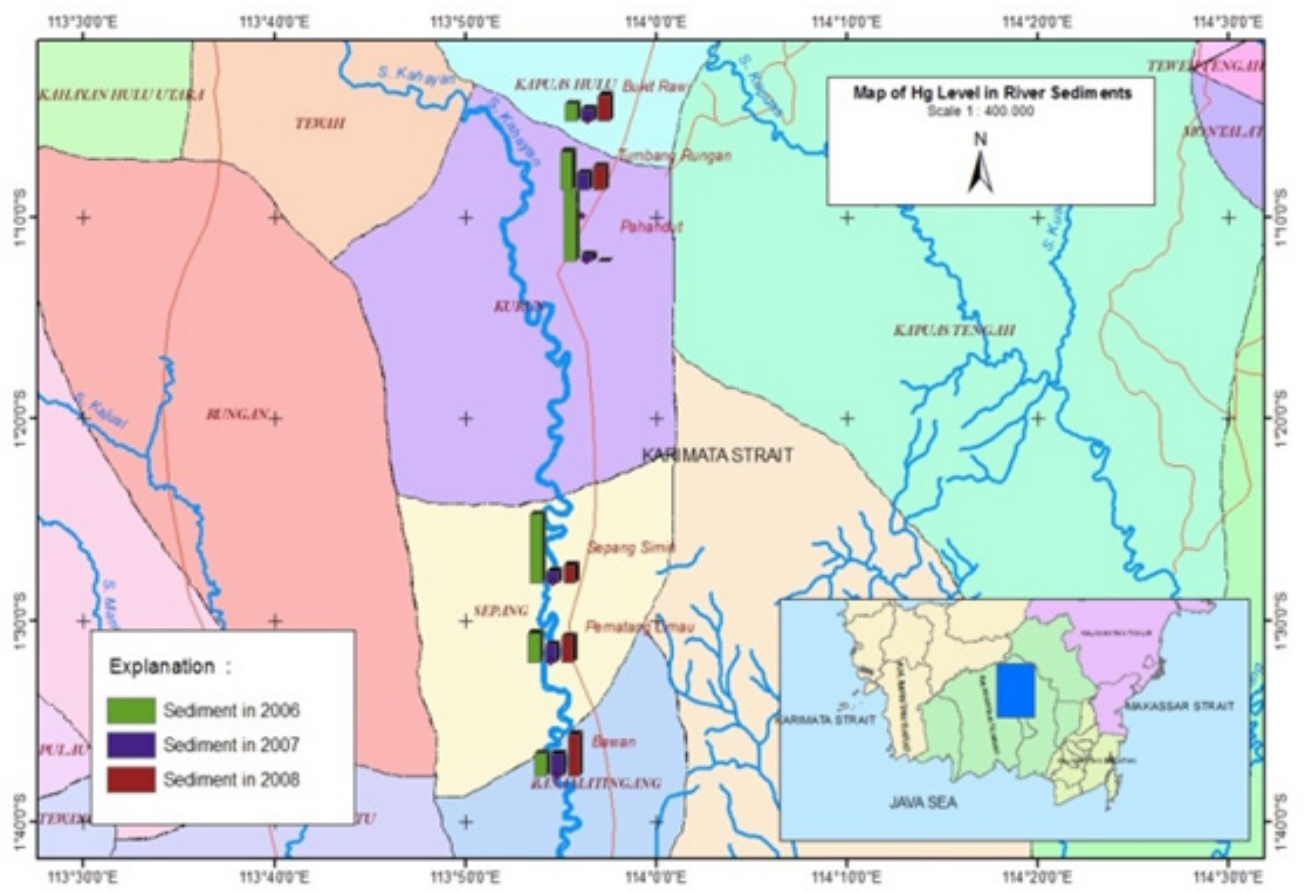

Gambar 1. Peta titik sampling Hg di Kalimantan Tengah 
Tabel 1. Konsentrasi merkuri dalam air sungai

\begin{tabular}{lcrrrr}
\hline \multicolumn{1}{c}{ Lokasi } & \multicolumn{4}{c}{ Kadar merkuri (mg/L) } \\
& $1999^{*}$ & $2006^{*}$ & $2007^{*}$ & $2008^{*}$ & $2018^{* *}$ \\
\hline S. Kahayan Hulu & & $<0,005$ & $<0,002$ & $<0,002$ & \\
S. Kahayan II & & $<0,005$ & $<0,002$ & $<0,002$ & \\
S. Kahayan III & & $<0,005$ & $<0,002$ & $<0,002$ & \\
S.Kahayan IV & & $<0,005$ & $<0,002$ & $<0,002$ & \\
S. Rungan & & $<0,005$ & $<0,002$ & $<0,002$ & \\
S. Kahayan VI & & $<0,005$ & $<0,002$ & $<0,002$ & \\
S. Rungan Atas & 0,008 & & & & \\
S. Rungan tengah & 0,033 & & & & \\
S. Kahayan Hulu & 0,042 & & & & \\
Pertemuan S. Kahayan dan S. Rungan & 0,013 & & & & \\
S. Kahayan Hilir & 0,015 & & & & 0,012 \\
Stasiun 1 & & & & 0,0003 \\
Stasiun 2 & & & & 0,00015 \\
Stasiun 3 & & & & 0,015 \\
Stasiun 6 & & & 0,0003 \\
Stasiun 7 & & & & 0,00008 \\
Stasiun 8 & & & & \\
Stasiun 9 & & & & \\
\hline
\end{tabular}

Sumber data: * Hasil Pengukuran P3KLL, BLI, KLHK

** Hasil Pengukuran Direktorat PB3, KLHK.

dilakukan di kecamatan yang berbeda, tetapi semua lokasi masih di wilayah administrasi Provinsi Kalimantan Tengah.

Konsentrasi $\mathrm{Hg}$ dalam sampel air sungai dibandingkan dengan baku mutu kriteria mutu air baku kelas I yang diatur dalam Peraturan Pemerintah No. 82 tahun 2001 tentang Pengelolaan Kualitas Air dan Pengendalian Pencemaran Air. Air baku kelas I adalah air yang peruntukannya dapat digunakan untuk air baku air minum, dan atau peruntukan lain yang mempersyaratkan mutu air yang sama dengan kegunaan tersebut. Air sungai di Kalimantan Tengah umumnya digunakan sebagai bahan baku air minum.

$\mathrm{Hg}$ dalam air sungai pada tahun 1999 terdeteksi dengan nilai $0,013-0,042 \mathrm{mg} / \mathrm{L}$. Nilai ini 13 sampai 42 kali lebih tinggi dari yang dipersyaratkan untuk air baku kelas 1 yaitu $0,001 \mathrm{mg} / \mathrm{L}$. Data tersebut mengindikasikan konsentrasi merkuri yang lebih tinggi pada bagian hulu, di mana aktivitas PESK lebih banyak. Hasil ini sama dengan beberapa penelitian sebelumnya, yang menyatakan bahwa semakin ke hilir sungai konsentrasi merkuri pada sungai sekitar PESK semakin kecil [14]-[17]. Hasil pengukuran tahun 2006, 2007, dan 2008 nilainya di bawah limit deteksi pada metode yang digunakan.

Lokasi pengambilan contoh uji pada tahun 2018 berada di Kelurahan Pangkut, Kecamatan Arut Utara, Kabupaten Kota Waringin Barat. Berdasarkan pengukuran pada tahun 2018, konsentrasi $\mathrm{Hg}$ terdeteksi pada semua lokasi titik sampling. Namun demikian, konsentrasi $\mathrm{Hg}$ yang melebihi baku mutu yang dipersyaratkan hanya pada dua lokasi. 


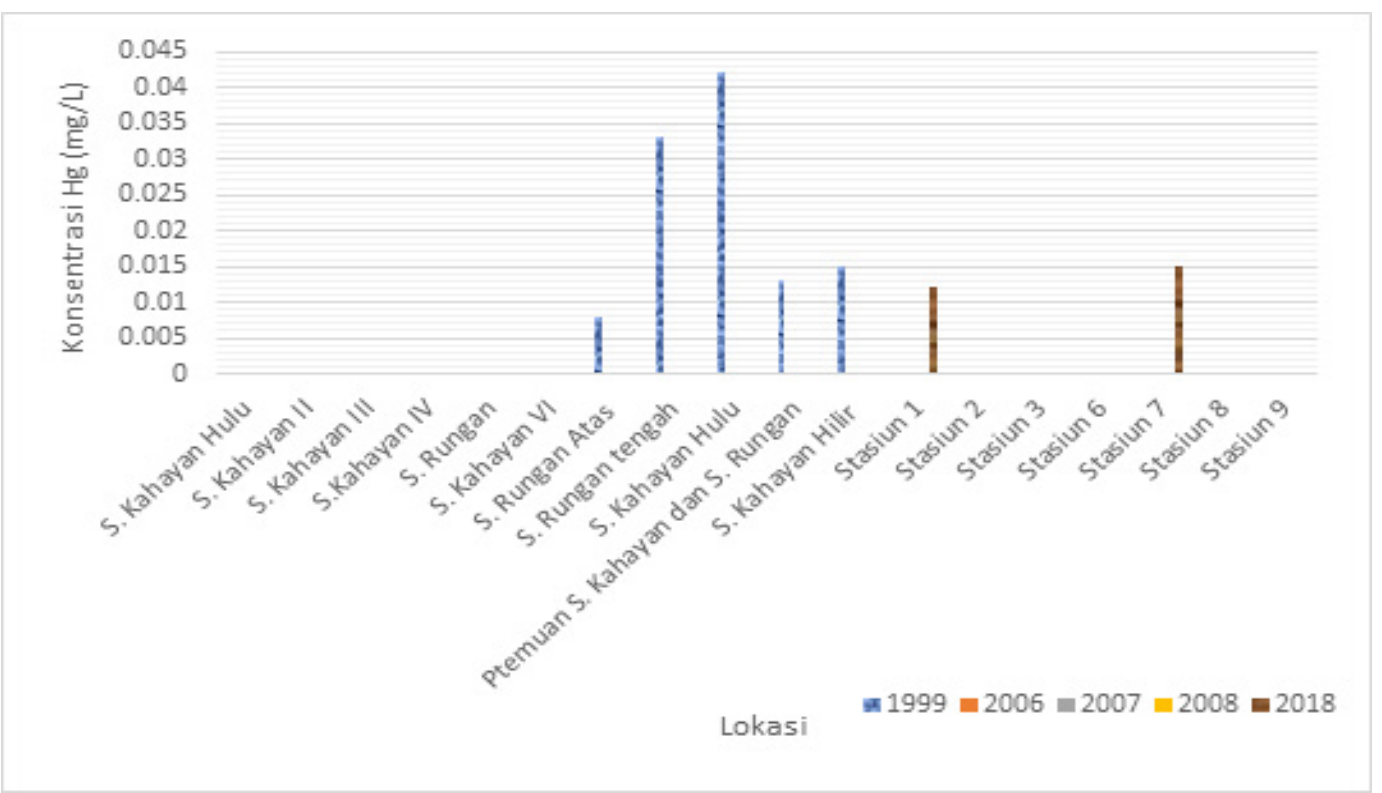

Gambar 2. Fluktuasi kandungan merkuri dalam air sungai

Hasil pengukuran konsentrasi merkuri menunjukkan bahwa ada peningkatan konsentrasi $\mathrm{Hg}$ pada tahun 2018. Hal ini mengindikasikan bahwa aktivitas PESK masih banyak menggunakan merkuri pada proses pengolahan tambangnya dan membuang limbahnya ke aliran sungai yang diteliti. Kasus-kasus yang sama ditemukan pada beberapa sungai lain di Indonesia, yang kemudian melalui proses rantai pangan, akan berpengaruh terhadap kesehatan makhluk hidup dan manusia di sekitarnya [18], [19].

\section{Konsentrasi Merkuri pada Sedimen}

Sedimen berada pada bagian dasar suatu sungai, merupakan endapan yang berasal dari aktivitas sungai maupun dari daratan yang masuk ke dalam sungai. Umumnya konsentrasi pencemar yang ada dalam sedimen lebih besar dibandingkan yang ada dalam air, mobilitas air yang lebih besar sedangkan sedimen cenderung statis sehingga logam dengan mudah terakumulasi dalam sedimen. Pada Tabel 2 di paparkan sedimen yang berasal dari Sungai Kahayan dan Sungai Rungan yang diambil tahun 1999, 2006, 2007, 2008, dan 2018. Saat ini Indonesia belum mempunyai baku mutu untuk sedimen, sehingga penulis membandingkannya dengan peraturan yang dimiliki negara lain yaitu Quality Guidelines for Fresh Water of Canadian Environmental Quality yang berasal dari Kanada (CEQ).

Hampir semua lokasi yang disampling pada tahun 1999 mempunyai nilai merkuri, terdeteksi di semua lokasi, di lokasi Sungai Ruang Atas 0,198 mg/L nilai ini melebihi dari persyaratan sedimen CEQ yang yaitu 0,17 mg/Kg. Pada tahun 2006, 2007, 2008 data $\mathrm{Hg}$ dalam sedimen berfluktuasi. Pada tahun 2006 di Sungai Kahayan hulu dan titik Kahayan VI nilainya 2 kali dari CEQ. Pada tahun 2007 Sungai Kahayan Hulu sedimen tidak terdeteksi. Data $\mathrm{Hg}$ dalam sedimen di stasiun 1 menunjukkan nilai yang lebih tinggi dari CEQ yaitu $0,45 \mathrm{mg} / \mathrm{L}$ lebih tinggi 2 kali dari batas yang dipersyaratkan.

Pada Gambar 2 menunjukkan nilai sedimen yang berfluktuatif di Kalimantan Tengah mulai tahun 1999, 2006, 2007, 2009 dan 2018. Hasil dari pemantauan setelah 10 tahun kemudian tidak berbanding lurus peningkatannya.

Sedimen adalah bahan padat baik mineral mapun organik yang berada dalam suspensi yang dipindahkan oleh udara, 
Tabel 2. Konsentrasi merkuri dalam sedimen

\begin{tabular}{lrrrrr}
\hline & \multicolumn{5}{c}{ Kadar merkuri (mg/Kg) } \\
& $1999^{*}$ & $2006^{*}$ & $2007 *$ & $2008^{*}$ & $2018^{* *}$ \\
\hline S. Kahayan Hulu & & 0.344 & $<0.06$ & 0.088 & \\
S. Kahayan II & & 0.145 & 0.091 & 0.130 & \\
S. Kahayan III & & 0.115 & 0.113 & 0.210 & \\
S. Kahayan IV & & 0.088 & 0.062 & 0.130 & \\
S. Rungan & & 0.193 & 0.086 & 0.120 & \\
S. Kahayan VI & & 0.421 & 0.035 & & \\
S. Rungan Hulu & 0.0291 & & & & \\
S. Rungan Atas & 0.198 & & & & \\
S. Rungan tengah & 0.07 & & & & \\
S. Kahayan Hulu & 0.071 & & & & 0.45 \\
Pertemuan S. Kahayan dan S. Rungan & 0.07 & & & & 0.046 \\
S. Kahayan Hilir & 0.0825 & & & & \\
Stasiun 1 & & & & & \\
Stasiun 2 & & & & & \\
Stasiun 3 & & & & & \\
Stasiun 4 & & & & & \\
\hline
\end{tabular}

Sumber data: * Hasil Pengukuran P3KLL, BLI, KLHK

** Hasil Pengukuran Direktorat PB3, KLHK.

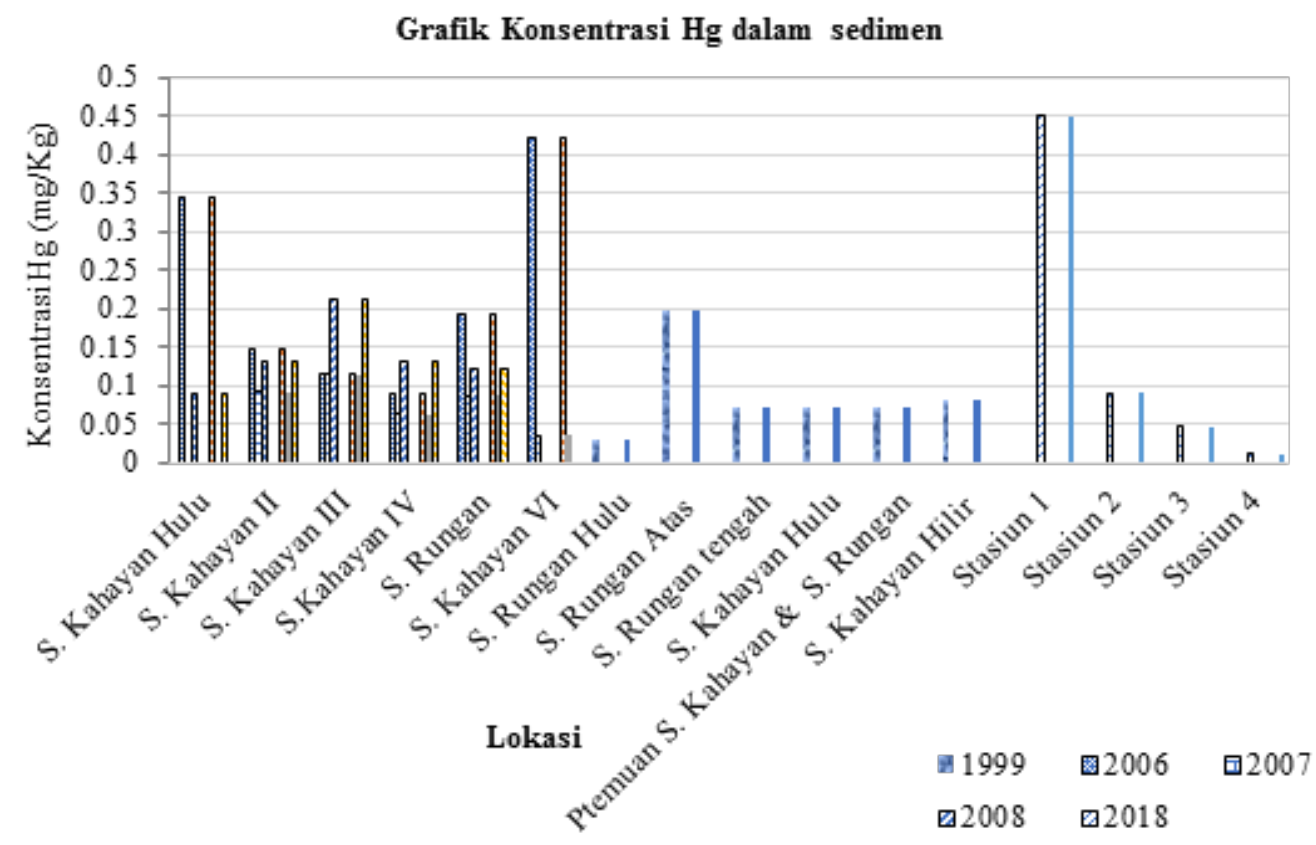

Gambar 3. Kandungan merkuri dalam sedimen 
air, gaya berat dan mengendap dalam permukaan bumi dan di bawah permukaan bumi. Di dalam air sungai terdapat partikelpartikel koloid yang tersuspensi di dalam air sungai. Partikel - partikel tersebut mempunyai kemampuan yang besar untuk mengabsorbsi ion-ion kation termasuk ionion logam berat seperti merkuri. Adanya merkuri pada sedimen sebagai indikator pencemaran dari limbah cair proses pertambangan emas di sekitar sungai yang terletak pada bagian hulu mengakibatkan terjadinya pengendapan sedimen di muara sungai. Kondisi sungai baik itu lebar sungai, arus air dan kondisi lingkungan di sekitar sungai sangat mempengaruhi kandungan logam berat khususnya di sedimen. Bila arus airnya deras, akan terjadi penumpukan endapan di estuari atau dekat dengan air laut. Sedangkan bila arusnya tidak deras, maka akan terjadi pengendapan di sepanjang aliran sungai sampai di muara sungai [20].

Kontaminasi merkuri pada sedimen sungai dapat mempengaruhi secara langsung atau tidak terhadap manusia. Dalam rantai makanan manusia berada pada posisi tertinggi, sedangkan organisme sederhana seperti plankton dan bentos berada pada posisi paling bawah. Plankton sebagai produsen dalam rantai makanan karena memiliki tingkat sensitivitas yang tinggi terhadap pencemar. Pencemaran merkuri juga bersifat bioakumulasi (bila kondisi memungkinkan) melalui rantai makanan sampai pada manusia [21]. Oleh karena itu seberapa pun besar merkuri pada sedimen diwaspadai, dan pemanfaatan sumberdaya dari sungai tersebut sudah berisiko [22].

\section{Konsentrasi Merkuri pada Ikan}

Jenis ikan yang diambil pada tahun 2007 dan 2008 yaitu ikan saluang dan ikan banta, dan ikan yang diambil pada tahun 2018 adalah ikan jeluah, ikan seluang, ikan salap, ikan lawing, ikan rengawan, ikan parau, ikan baung, dan ikan ketulai.

Persyaratan kandungan $\mathrm{Hg}$ dalam ikan mengacu ke SNI 7387:2009 tentang Baku Mutu Cemaran Logam dalam pangan untuk ikan dan produk perikanan yang mensyaratkan maksimal kandungan $\mathrm{Hg}$ dalam ikan sebesar $0,5 \mathrm{mg} / \mathrm{kg}$. Hasil penelitian menunjukkan bahwa nilai kadar merkuri pada ikan yang diambil pada tahun 2007, 2008, dan 2018 berada di bawah yang dipersyaratkan. Hal ini menunjukkan bahwa

Tabel 3. Konsentrasi merkuri dalam ikan

\begin{tabular}{|c|c|c|c|}
\hline \multirow{2}{*}{ Lokasi/jenis ikan } & \multicolumn{3}{|c|}{ Kadar merkuri (Hg) (mg/Kg) } \\
\hline & $2007 *$ & $2008 *$ & $2018 * *$ \\
\hline S. Kahayan Hulu (ikan saluang) & 0.125 & & \\
\hline S. Kahayan II (ikan Banta) & 0.224 & & \\
\hline S.Kahayan IV (ikan saluang) & & 0.22 & \\
\hline Stasiun 1 (ikan jeluah) & & & 0.2 \\
\hline Stasiun 1 (ikan seluang) & & & 0.1 \\
\hline Stasiun 1 (ikan salap) & & & 0.08 \\
\hline Stasiun 9 (ikan lawang) & & & 0.21 \\
\hline Stasiun 9 (ikan rengawan) & & & 0.21 \\
\hline Stasiun 9 (ikan parau) & & & 0.22 \\
\hline Stasiun 9 (ikan baung) & & & 0.21 \\
\hline Stasiun 9 (ikan ketulai) & & & 0.2 \\
\hline
\end{tabular}

Sumber data: * Hasil Pengukuran P3KLL, BLI, KLHK

** Hasil Pengukuran Direktorat PB3, KLHK. 


\section{Grafik Konsentrasi Merkuri dalam Ikan}

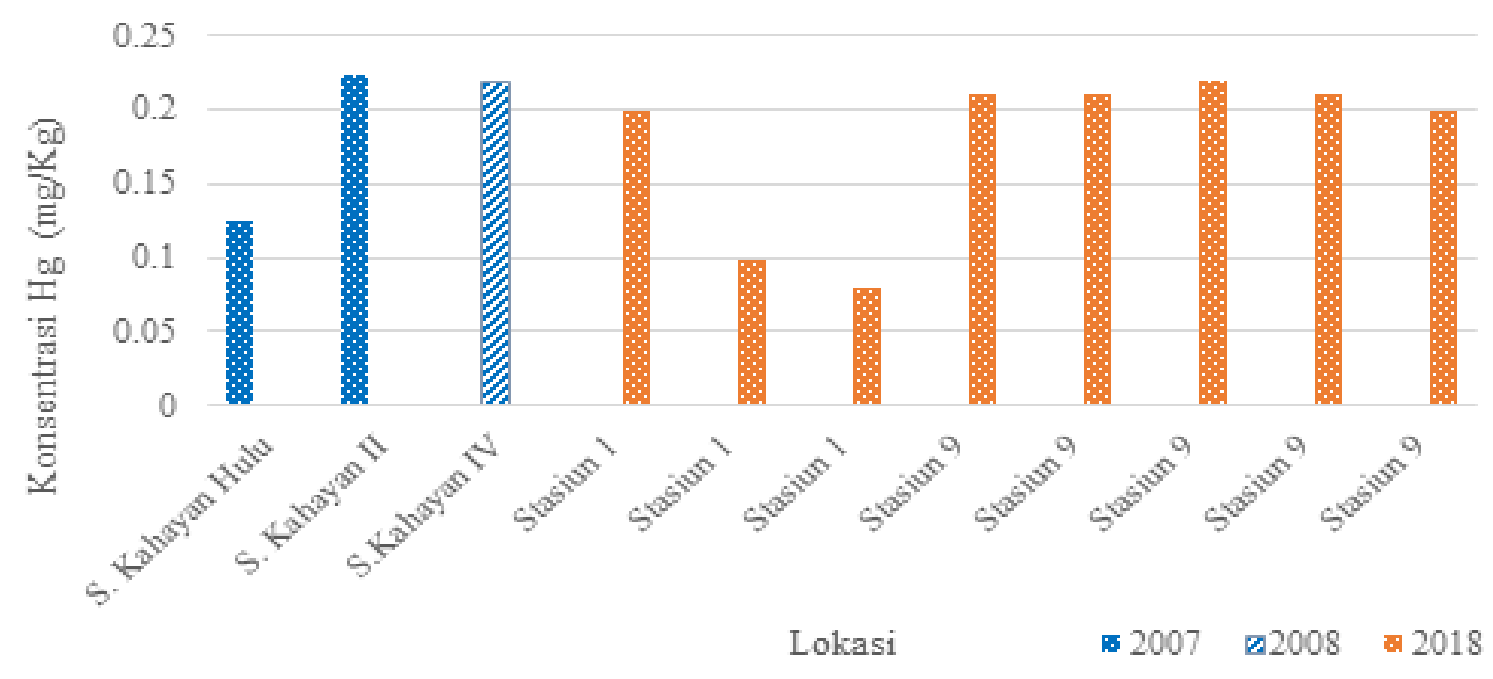

Gambar 4. Konsentrasi merkuri dalam ikan

ikan di lokasi kegiatan aman dikonsumsi.

Data hasil pemantauan (Tabel 3 dan Gambar 4) menunjukkan terdeteksinya kadar merkuri dalam jaringan berbagai jenis ikan air tawar yang bernilai ekonomi. Hal ini bisa dijadikan indikasi rute paparan merkuri pada manusia. Rute paparan merkuri kepada manusia bisa melalui udara, air minum, dan makanan [2]. Konsentrasi merkuri di sebagian besar bahan makanan sering tidak terdeteksi atau sangat kecil. Namun demikian, beberapa penelitian sebelumnya menemukan kadar merkuri pada ikan, seperti penelitian [23] di Sekotong, yakni kadar merkuri pada ikan sebesar $1.000-1.400$ kali lebih tinggi daripada yang diperbolehkan WHO (0,5 ppb). Oleh karena itu, sekecil apa pun kadar merkuri yang terdeteksi, jika terakumulasi pada ikan [23]-[25] dan kemudian pada jaringan pangan yang lebih tinggi, dan selanjutnya masuk ke manusia, maka akan meningkatkan risiko kesehatan [4], [17], [26], [27].

Ikan dan mamalia laut adalah sumber dominan paparan merkuri terhadap manusia, terutamadalam bentuk senyawa metilmerkuri (70-90\% dari total). Konsentrasi normal dalam jaringan yang dapat dimakan dari berbagai spesies ikan mencakup kisaran yang luas, dari 50 hingga $1.400 \mathrm{ng} / \mathrm{g}$ berat segar tergantung pada faktor-faktor seperti $\mathrm{pH}$, potensi redoks air dan spesies, umur dan ukuran ikan. Ikan predator besar mengandung konsentrasi rata-rata $\mathrm{Hg}$ tertinggi [28][29] karena sifatnya yang bioakumulasi. Standar kandungan $\mathrm{Hg}$ dalam ikan tercantum dalam the US 'Food and Drug Administration' (FDA) tentang standar konsentrasi $\mathrm{Hg}$ dalam semua jenis ikan yang dikonsumsi manusia adalah 1 ppm [28] dan SNI 7387:2009 tentang baku mutu cemaran logam dalam pangan untuk ikan dan produk perikanan adalah 0,5 ppm [30]. Data hasil pemantauan dari tahun 2007, 2008, dan 2018 kandungan $\mathrm{Hg}$ dalam jaringan beberapa jenis ikan air tawar bernilai ekonomi masih memenuhi standar yang telah ditetapkan.

\section{SIMPULAN}

Secara umum kandungan merkuri dalam air sungai masih berada di bawah standar air baku kelas I (Peraturan Pemerintah Nomor 82 Tahun 2001). Merkuri yang terkandung dalam sampel ikan air tawar dari sungai di 
sekitar PESK ditemukan pada kisaran 0,08 $-0,224 \mathrm{mg} / \mathrm{kg}$. Nilai ini masih berada di bawah nilai persyaratan kontaminasi logam pada ikan sesuai SNI 7387:2009 (0,5 mg/ $\mathrm{kg}$ ). Kandungan merkuri dalam sedimen antara 0,0291-0,45 mg/kg, di mana beberapa lokasi sudah melampaui baku mutu Quality Guidelines for Fresh Water of Canadian Environmental Quality (CEQ).

\section{UCAPAN TERIMAKASIH}

Penulis ingin mengucapkan terima kasih kepada Direktorat Pengelolaan Bahan Berbahaya Beracun(Dir. PB3)-Kementerian Lingkungan Hidup dan Kehutanan atas data-data yang diberikan kepada kami. Terimakasih juga kepada semua tim teknis di Laboratorium Air dan Laboratorium B3 Pusat Penelitian dan Pengembangan Kualitas dan Laboratorium Lingkungan (P3KLL), Kementerian Lingkungan Hidup dan Kehutanan.

\section{DAFTAR PUSTAKA}

1. T. Lestari, "Faktor faktor yang Berhubungan dengan Keracunan Merkuri ( $\mathrm{Hg})$ pada Penambang Emas Tanpa Ijin (PETI) di Kecamatan Kurun, Kabupaten Gunung Mas, Kalimatan Tengah," tesis Univ. Diponegoro, Semarang, 2010.

2. E. E. Kwaansa-Ansah, E. K. Armah, and F. Opoku, "Assessment of total mercury in hair, urine and fingernails of small-scale gold miners in the Amansie West District, Ghana," J. Heal. Pollut., vol. 9, no. 21, 2019.

3. R. Pérez, T. Suelves, Y. Molina, F. CorpasBurgos, and V. Yusà, "Biomonitoring of mercury in hair of children living in the Valencian Region (Spain). Exposure and risk assessment," Chemosphere, vol. 217, pp. 558-566, 2019.

4. B. Du, P. Li, X. Feng, G. Qiu, J. Zhou, and L. Maurice, "Mercury exposure in children of the wanshan mercury mining area, Guizhou, China," Int. J. Environ. Res. Public Health, vol. 13, no. 11, 2016.
5. M. Rajaee, R. N. Long, E. P. Renne, and N. Basu, "Mercury exposure assessment and spatial distribution in a Ghanaian smallscale gold mining community," Int. J. Environ. Res. Public Health, vol. 12, no. 9, pp. 10755-10782, 2015.

6. M. Nevárez, L. O. Leal, and M. Moreno, "Estimation of seasonal risk caused by the intake of lead, mercury and cadmium through freshwater fish consumption from urban water reservoirs in arid areas of northern Mexico," Int. J. Environ. Res. Public Health, vol. 12, no. 2, pp. 18031816, 2015.

7. W. Widodo, "Pencemaran air raksa $(\mathrm{Hg})$ sebagai dampak pengolahan bijih emas di Sungai Ciliunggunung, Waluran, Kabupaten Sukabumi," Indones. J. Geosci., Nov. 2014.

8. Y. Ismawati et al., "Mercury trade and supply in Indonesia," no. June, 2017.

9. T. Tomiyasu, Y. Kono, H. Kodamatani, N. Hidayati, and J. S. Rahajoe, "The distribution of mercury around the smallscale gold mining area along the Cikaniki river, Bogor, Indonesia," Environ. Res., vol. 125, pp. 12-19, Aug. 2013.

10. D. E. Bruno et al., "Artisanal and smallscale gold mining, meandering tropical rivers, and geological heritage: Evidence from Brazil and Indonesia," Sci. Total Environ., vol. 715, p. 136907, 2020.

11. K. Macdonald, M. Lund, and M. Blanchette, "Impacts of Artisanal Small-Scale Gold Mining on Water Quality of a Tropical River (Surow River, Ghana)," $10^{\text {th }}$ Int. Conf. Acid Rock Drain. IMWA Annu. Conf., no. July 2016, pp. 1-12, 2015.

12. G. Martinez et al., "Mercury contamination in riverine sediments and fish associated with artisanal and small-scale gold mining in Madre de Dios, Peru," Int. J. Environ. Res. Public Health, vol. 15, no. 8, pp. 1-15, 2018.

13. J. Zhang et al., "Comparison of toxic metal distribution characteristics and health risk between cultured and wild fish captured from Honghu city, China," Int. J. Environ. Res. Public Health, vol. 15, no. 2, 2018.

14. C. S. Green, P. J. Lewis, J. R. Wozniak, P. E. Drevnick, and M. L. Thies, "A 
comparison of factors affecting the smallscale distribution of mercury from artisanal small-scale gold mining in a Zimbabwean stream system," Sci. Total Environ., vol. 647, no. July, pp. 400-410, 2019.

15. B. Niane, S. Guédron, F. Feder, S. Legros, P. M. Ngom, and R. Moritz, "Impact of recent artisanal small-scale gold mining in Senegal: Mercury and methylmercury contamination of terrestrial and aquatic ecosystems," Sci. Total Environ., vol. 669, no. March, pp. 185-193, 2019.

16. Widodo, "Pencemaran air raksa $(\mathrm{Hg})$ sebagai dampak pengolahan bijih emas di Sungai Ciliunggunung, Waluran, Kabupaten Sukabumi," J. Geol. Indones., vol. 3, no. 3, pp. 139-149, 2008.

17. N. M. Barkdull, G. T. Carling, K. Rey, and D. F. Yudiantoro, "Comparison of Mercury Contamination in Four Indonesian Watersheds Affected by Artisanal and Small-Scale Gold Mining of Varying Scale," Water. Air. Soil Pollut., vol. 230, no. 9, p. 18 pp, 2019.

18. N. A. Gafur, M. Sakakibara, S. Sano, and K. Sera, "A case study of heavy metal pollution in water of Bone River by Artisanal Small-Scale Gold Mine Activities in Eastern Part of Gorontalo, Indonesia," Water (Switzerland), vol. 10, no. 11, p. 11, 2018.

19. S. Bose-O'Reilly, L. Bernaudat, U. Siebert, G. Roider, D. Nowak, and G. Drasch, "Signs and symptoms of Mercury-exposed gold miners," Int. J. Occup. Med. Environ. Health, vol. 30, no. 2, pp. 249-269, 2017.

20. A. A. Pesantes, E. P. Carpio, T. Vitvar, M. M. M. López, and J. M. MenéndezAguado, "A multi-index analysis approach to heavy metal pollution assessment in river sediments in the Ponce Enríquez Area, Ecuador," Water (Switzerland), vol. 11, no. 3, p. 12, 2019.

21. N. Basu et al., "Integrated Assessment of Artisanal and Small-Scale Gold Mining in Ghana-Part 1: Human Health Review," Int. J. Environ. Res. Public Health, vol. 12, no. 5, pp. 5143-5176, 2015.
22. G. Genchi, M. S. Sinicropi, A. Carocci, G. Lauria, and A. Catalano, "Mercury exposure and heart diseases," Int. J. Environ. Res. Public Health, vol. 14, no. 1, p. 14, 2017.

23. M. Junaidi, B. D. Krisnayanti, Juharfa, and C. Anderson, "Risk of mercury exposure from fish consumption at artisanal smallscale gold mining areas in West Nusa Tenggara, Indonesia," J. Heal. Pollut., vol. 9, no. 21, 2019.

24. C. Salazar-Camacho, M. Salas-Moreno, S. Marrugo-Madrid, J. Marrugo-Negrete, and S. Díez, "Dietary human exposure to mercury in two artisanal small-scale gold mining communities of northwestern Colombia," Environ. Int., vol. 107, no. May, pp. 47-54, 2017.

25. K. Bentley and A. Soebandrio, "Arsenic and mercury concentrations in marine fish sourced from local fishermen and fish markets in mine-impacted communities in Ratatotok Sub-district, North Sulawesi, Indonesia," Mar. Pollut. Bull., vol. 120, no. 1-2, pp. 75-81, 2017.

26. M. C. N. Pinheiro et al., "Temporal evolution of exposure to mercury in riverside communities in the Tapajós Basin, from 1994 to 2010," Bull. Environ. Contam. Toxicol., vol. 89, no. 1, pp. 119-124, 2012.

27. M. M. Sari, T. Inoue, Y. Matsumoto, and K. Yokota, "Relating food and human hair to assess mercury exposure levels in Poboya, Central Sulawesi, Indonesia," Int. J. Environ. Sci. Technol., vol. 14, no. 3, pp. 463-472, 2017.

28. G. Pandey, "Contamination of Mercury in Fish and Its Toxicity To Both Fish and Humans: an Overview," Int. Res. J. Pharm., vol. 3, no. 11, pp. 44-47, 2012.

29. E. J. Zillioux, "Mercury in Fish: History, sources, pathways, effects, and indicator usage," Environ. Indic., no. Clarkson 1997, pp. 743-766, 2015.

30. NN, "SNI 7388: 2009 tentang Batas Maksimum Cemaran Mikroba dalam Pangan.," Badan Stand. Nasional. Jakarta., p. 17, 2009. 